\title{
Development and Security
}

\author{
By Frances Stewart
}

WORKING PAPER 3

Centre for Research on Inequality, Human Security and Ethnicity, CRISE

Queen Elizabeth House, University of Oxford 


\title{
Development and Security
}

\begin{abstract}
This paper reviews the connections between development and security both within developing countries and globally. It interprets security as human security, and within this category focuses on political violence as an important source of insecurity. Three connections are hypothesised: that human security forms an important part of people's wellbeing and is therefore an objective of development; that lack of human security has adverse consequences on economic growth and poverty and thereby on development; and that lack of development, or imbalanced development that involves sharp horizontal inequalities, is an important cause of conflict. Evidence supporting these relationships is surveyed for developing countries. A brief overview of the current global situation suggests similar relationships obtain. Hence for both developing countries and to prevent global terrorism, it is essential to promote inclusive development. A focus on military solutions alone - the usual interpretation of 'security' - will not succeed.
\end{abstract}




\title{
Development and Security
}

\author{
by Frances Stewart*
}

\section{Introduction}

This paper considers some of the connections between development and security, both nationally and globally. Three types of connection will be distinguished:

- The immediate impact of security/insecurity on well-being and consequently development achievements (or the ways in which security forms part of the definition of development) - i.e., security's role as part of our objectives.

- The way that insecurity affects (non-security) elements of development and economic growth, or the security instrumental role.

- The way development affects security, or the development instrumental role.

To the extent that these three-way connections exist, policies towards security may become one part of development policy because in so far as they enhance security, they will contribute to development; and policies towards development may become part of security policies because enhanced development increases security. Hence the connections suggest a quite radical revision of both security and development policies. ${ }^{1}$

The aim of this paper is to consider the three connections in developing countries and also globally - in more depth vis-à-vis developing country experience and policies, since I have been working on these issues for the last ten years, but also exploring the global connections-at a more superficial level. Acknowledging these three-way connections and consequently the generic policy implications just noted for the multiple roles of development and security policies is not sufficient to identify the actual development or security policies appropriate in specific cases. These depend on precisely how the three-way connections work, as well as the political economy of policy-making in particular contexts. The paper will make some suggestions here, but this is an area where more research is needed.

The paper is organised as follows. The next three sections consider each of the three connections described separately, in the order presented above, for developing countries. Section $\mathrm{V}$ will explore whether the connections identified at a national developing country level can be translated to the international level.

\section{Security as an Intrinsic Aspect of Development}

Development, which signifies progress in human well-being, used to be equated with economic growth, but it is now widely acknowledged that this is a very inadequate characterisation. As long noted, average per capita incomes are one important means to achieve such progress, but not the only one. ${ }^{2}$ Not only does average income fail to capture distribution across households, but it also may not be a good indicator of many important aspects of human well-being, such as people's health, education or their security. A series of alternative objectives have been put forward,

\footnotetext{
* This paper was prepared for the Security and Development Workshop, January 25-26, 2004, associated with the Fifth Annual Global Development Conference Security and Development Workshop, January 25-26, 2004.

${ }^{1}$ One connection NOT covered by this paper is that of the securitisation of development - i.e., the way development agencies may need to use military protection or even force to deliver aid.

${ }^{2}$ Seers (1971) was one of the first to point out the defects of GDP as a measure of development.
} 
one of the earliest being the PQLI (Physical Quality of Life Index). Sen has suggested that the development objective should be the enhancement of people's capabilities, or the opportunities open to people of being and doing a variety of things. UNDP's Human Development Report defined the objective succinctly as enlarging people's choices in a way which enables them to lead longer, healthier and fuller lives. ${ }^{3}$

These are important advances, but do not explicitly incorporate security as an aspect of development. People may have the potential to do and be many things, yet this potential may be cut off, or people's sense of well-being may be seriously adversely affected with high levels of insecurity. Such insecurity includes the possibility of economic vicissitudes, health crises, and injury or death as a result of criminal or political violence. Sustained political violence may lead to the break-up of communities and families, forced migration and the need to re-establish lives in strange and alien environments, or even a suspended existence in refugee camps. There is no question that if such events are widespread, they have a serious negative impact on many people's lives, and therefore adversely affect the achievement of development.

The UNDP developed the concept of 'human security' to encompass not just the achievement of minimal levels of material needs, but also the absence of severe threats to them of an economic or political kind: 'Job security, income security, health security, environmental security, security from crime - these are the emerging concerns of security all over the world'. According to Sen (1999), 'Human security is concerned with reducing and - when possible - removing the insecurities that plague human lives' (p. 8). The definition has been expanded by the Commission on Human Security:

Human security in its broadest sense embraces far more than the absence of violent conflict. It encompasses human rights, good governance, access to education and health care, and ensuring that each individual has opportunities and choices to fulfil his or her own potential...Freedom from want, freedom from fear and the freedom of the future generations to inherit a healthy natural environment - these are the interrelated building blocks of human, and therefore national security (CHS 2003, p. 4).

This definition of security is too extensive for my purposes because it covers much of what is normally included in human development, i.e., levels of achievement as well as risks, ${ }^{4}$ and also includes economic sources of insecurity as well as those arising from violence. For the purpose of this paper, I shall interpret security more narrowly, as occurring where there are low levels of insecurity, where insecurity consists in inter-personal violence or the risk of it. Inter-personal violence may have criminal or political objectives (or both). I am defining such insecurity as arising at the individual or community level. Hence it is not the same as national insecurity, since it is experienced at the level of the individual, community or group, rather than that of the nation. However, national insecurity (invasion from outside, or a high risk of it) can be an important source of such individual or community insecurity, as the current Iraq situation demonstrates.

\footnotetext{
${ }^{3}$ The first UNDP Human Development Report stated that: 'The basic objective of development is to create an enabling environment for people to enjoy long, healthy and creative lives' (UNDP 1990, p. 9), and defined human development as 'a process of enlarging people's choices' (p. 10).

${ }^{4}$ Although Sen suggests that, in comparison with Human Development, it focuses more on the 'downside risks' (CHS, 2003, page 8).
} 
Achievement of the development objective defined as the enlargement of human choices is adversely affected by such individual/community insecurity because it cuts life short and thwarts the use of human potential. Moreover, if we take a more utilitarian approach to the definition of development - that it furthers human happiness - insecurity has severe adverse affects. In consultations with poor people, the need for security comes up as one of their foremost priorities, even in peaceful societies (e.g., Narayan-Parker and Patel 2000). No such consultations have taken place during high-levels of conflict, but retrospective analysis produces similar answers, as one would expect.

Thus individual and community security are an important dimension of development. Their absence - even if progress is being made on all other aspects of development - then seriously detracts from development achievements. Development and security are therefore linked in themselves, even in the absence of the causal connections between them to be discussed below.

\section{The Development Costs of Insecurity}

Some development costs are obvious. People who join the fighting forces, who are killed or flee, can no longer work productively; schools, power stations and/or roads that are destroyed reduce the productive capacity of the economy. There are also more complex interactions between events associated directly with war (fighting, movement of people, deaths, physical destruction, international embargoes, military expenditures) and developments in the macro, meso and microeconomy which mostly lead to adverse changes in individual entitlements, both economic and social. To take one example, movement of manpower may reduce the production of exports, thereby reducing foreign exchange earnings, import potential and consequently further constraining output, leading to a decline in employment and earnings. However, we should note that there can be positive indirect effects as resources are used more fully and efficiently. These positive effects seem to have occurred in some countries in the second World War.

The extent of the effects and their distribution depend on the nature of the conflict. More serious conflict (involving many deaths and prolonged over a long period) may, obviously, be expected to have a worse impact than smaller, shorter wars; while conflicts confined to the periphery of the country appear to be less adverse than those that range over the heartland of the economy. Conflicts that occur in rather rigid economies are likely to have more negative impact than those that occur where the economy is flexible and resources can readily be redeployed. Moreover, the social impact of conflict depends greatly on the nature of the government. When governments are strong and relatively benign, they can sustain social services (e.g., Mozambique and Nicaragua), while weak governments that are further undermined by conflict are unable to do so (Uganda in the 1970s and mid-1980s). Meanwhile, governments that lean heavily to one side may deliberately withhold services from part of the population (Sudan).

There are serious methodological problems in identifying precise effects, including huge data deficiencies, and the difficult question of the counterfactual, or what would have happened in the absence of war. The latter issue is a particularly relevant one because many countries at war have previously been doing badly both economically and with respect to social indicators, and continued weak performance is not necessarily due to the conflict. Moreover, the debt crisis hit many poor developing countries simultaneously with some recent wars, with some similar effects to those of conflict. A variety of methods can be used to try and separate the consequences of 
conflict from those of other developments. Probably the most reliable is to compare the performance of war-affected countries with similar countries not affected by war in the same region (though, because of spillover effects, these countries too are typically adversely affected so that this method will understate the costs). The problem of inadequate data however remains very serious, irrespective of the method adopted.

Exploring the economic behaviour of the twenty-five countries worst affected by conflict from 1960 to 1995 (a list of these countries is appended) led to the following general findings about economic behaviour during wars: ${ }^{5}$

- Economic growth was almost always negatively affected, sometimes dramatically so, such as in Mozambique and Nicaragua; but aggregate output was least affected where the conflict was confined to one geographic region, as in Sri Lanka. The agricultural sector was usually particularly badly hit, especially if people were forced to move in the course of the conflict. This evidence is borne out by econometric estimates which suggest that economies in conflict on average grow 1-2 per cent more slowly than peacetime economies.

- Exports were invariably negatively affected. This resulted from the general fall in production, a shift towards domestic markets, and disruptions in international markets. Nonetheless, import capacity often held up, financed by aid and private credit, with the result that foreign debt spiralled. Foreign exchange, however, tended to be diverted towards military expenditure and essential consumption goods, leading to a shortage of foreign exchange for economic inputs. In Nicaragua, this was one of the main causes of a collapse in production.

- There were sectoral shifts with a switch to subsistence and informal activities, including simple manufacturing production, production of previously outlawed commodities (notably drugs) and trading (particularly smuggling).

- Consumption per head inevitably fell with per capita GDP, though generally not proportionately.

- Government revenue as a share of GDP mostly fell among countries in conflict, but contrary to expectations, not always. In Nicaragua and Mozambique, it rose quite sharply, yet in others cases government revenue raising was totally undermined - for example in Uganda. This difference was critical in determining whether the government could sustain public services. Government expenditure invariably rose more than revenue, and budget deficits widened, financed by a combination of foreign and domestic borrowing, and increased money supply. But despite the rising budget deficit, inflation was mostly quite moderate and hyperinflation was rare.

- The share of government expenditure going to the military invariably rose (Figure One), and mostly the share of social expenditure fell. Public provision of social services fell in most cases, dramatically in those cases where government revenue collapsed, for example in Uganda and Afghanistan. Yet both Nicaragua and Mozambique gave increased priority to social expenditure compared with the pre-war situation.

- There were invariably heavy development costs as each type of capital was subject to destruction (including physical plant, land, human resources, social and organisational capital), and new investment was reduced. Government investment and large-scale foreign and private investment fell quite sharply, although in general aggregate investment did not fall by as much as domestic savings, owing to increased foreign savings. Investment has been found to

\footnotetext{
${ }^{5}$ Because of data deficiencies, analysis of most issues was confined to a subset of the 25 countries. The analysis and findings are derived mainly from Stewart, Fitzgerald et al. (2001).
} 
decline especially sharply when the conflict is extensive. ${ }^{6}$ Some new forms of capital emerged, however, including social and organisational, with informal systems of banking and quasi-government structures developing in rebel-held areas.

\section{Figure One}

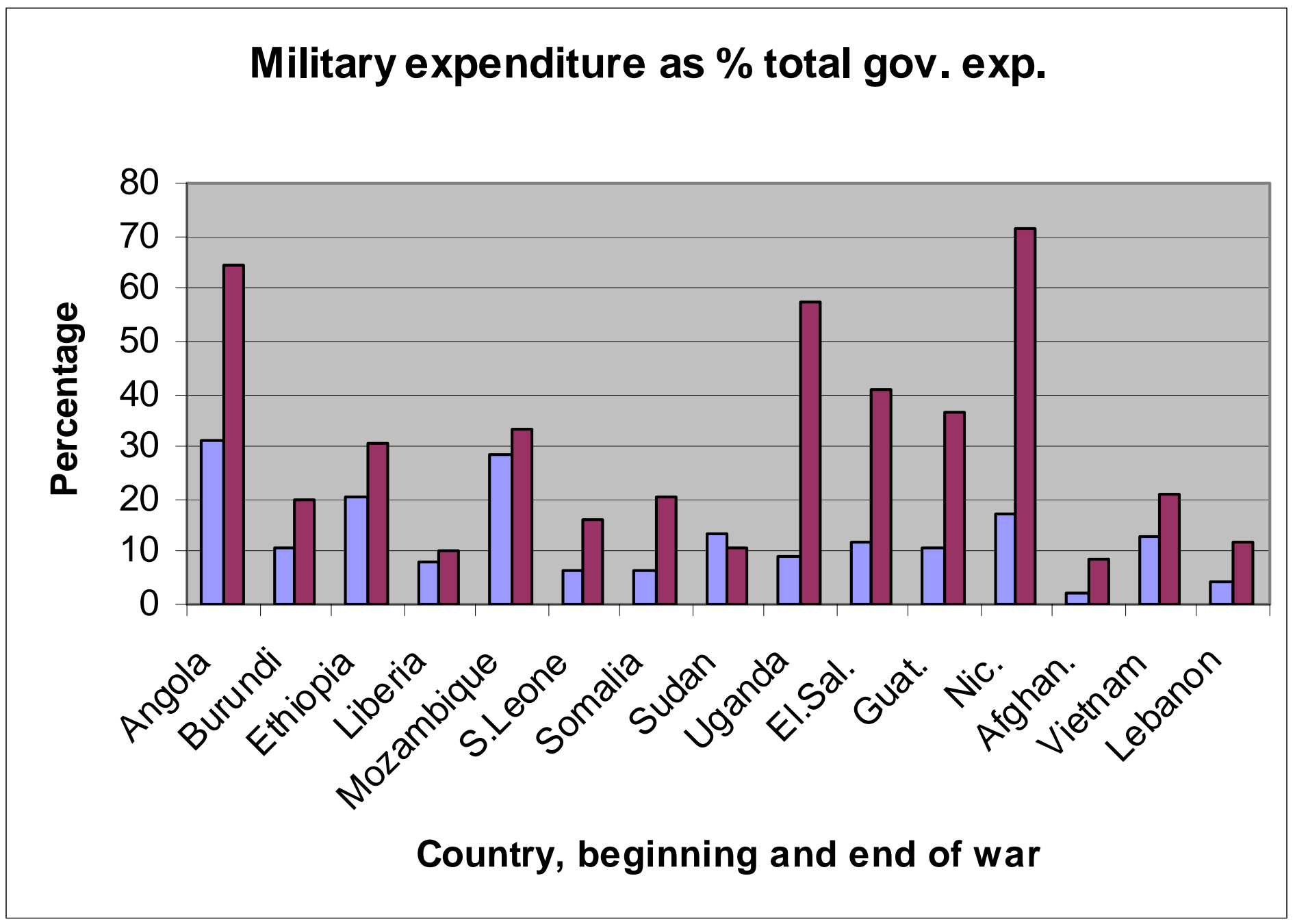

Source: derived from Stewart, Fitzgerald and Associates, 2001, vol 1 Table 4.9

\footnotetext{
${ }^{6}$ For example, Imai and Weinstein (2000) find that the investment share drops by 4 per cent when conflict extends to one half of the country.
} 
One way of analysing the effects of conflicts on human well-being is in terms of entitlement failures, adopting and extending Sen's concept. Entitlements represent people's command over resources. Extreme human suffering results when household (or individual) entitlements fall below what is needed for subsistence. The complex economic effects of war can change each of these types of entitlement quite dramatically.

The following impact of conflicts on different types of entitlements was observed:

- Market entitlements (arising in the market) generally fell with the decline of formal sector production. Rising inflation, associated with increasing budget deficits, further undermined real wages.

- Direct entitlements (from subsistence production) rose in some areas (for example, in Uganda in the 1970s), but not where the war was such as to make production difficult or impossible (for example, in the war area of the Lowero triangle in Uganda in the mid-1980s).

- Public entitlements (flowing from the state) were mostly adversely affected, especially in those countries where the tax capacity collapsed. But in a few cases, a determined government managed to preserve and even increase these entitlements. In Mozambique, Sudan and Nicaragua social expenditure per head rose markedly during conflict, but in almost every other country it fell sharply.

- Civic entitlements (resulting from NGO or community activity) compensated for losses in other types of entitlement in some cases: communities, NGOs and rebel governmental structures were important, for example in Sri Lanka. In Afghanistan in the 1990s, NGOs provided most of the (highly deficient) services available. But where the wars were most fierce, the ability of communities and NGOs to respond was reduced.

- Extra-legal entitlements (arising e.g., from theft) invariably rose: but while there were gainers there were also losers, who often suffered physical harm as well as loss of commodities. In some cases new sources of trade and gain (some legal, some illegal) emerged (as with the informal sector in Mozambique and poppy production in Afghanistan) providing net additions to entitlements.

On balance, entitlements fell as the downward movement in market entitlements was larger than compensatory effects from other types of entitlement. This is indicated by the reduction in consumption levels and worsening availability of calories per head, which fell in most countries. While the drop was especially sharp in Liberia, Afghanistan and Cambodia, the indicator reached grossly inadequate levels in many other countries too (Figure Two). 
Figure Two

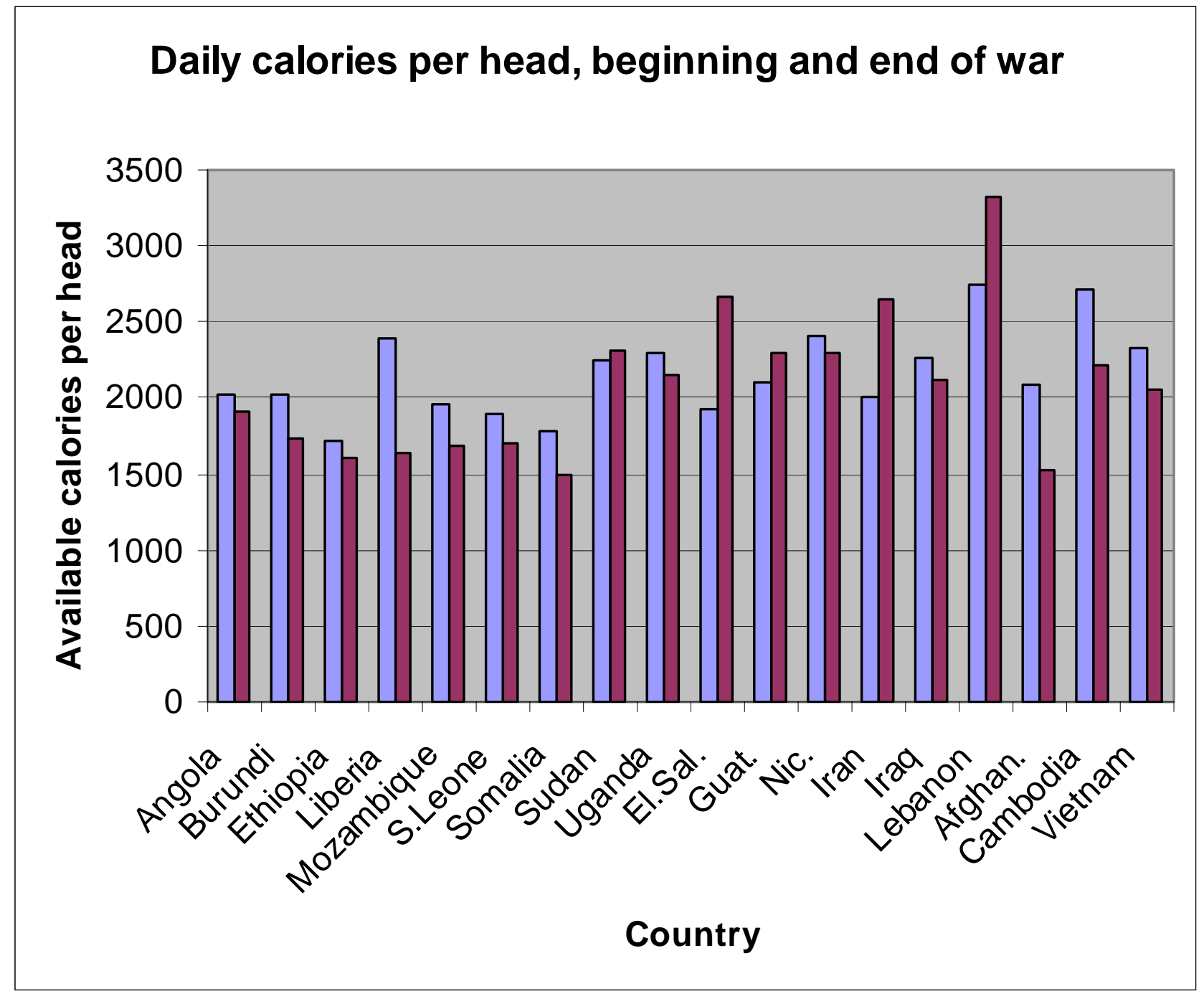

Source: derived from Stewart, Fitzgerald and Associates, 2003, vol 1, Table 4.11 
All the country studies indicated a highly unequal distribution of the costs and benefits of conflict. In Sudan, for example, Southerners were severely and deliberately deprived, while particular Northern groups - especially the army itself - gained from the war. In Sierra Leone, war-gangs on both sides gained from looting at the expense of the majority of the population. The middle classes generally were better able to protect themselves than the poor. In Afghanistan, for example, the middle classes were able to leave the country while the poor mostly lacked the resources to move. It is important to identify the gainers as well as the losers, because the former have a motive for starting and prolonging conflict, even if society as a whole loses.

As a whole, there were heavy human costs in most countries, with deteriorating nutrition, health and educational standards, and worsening infant mortality compared with regional trends in thirteen out of seventeen cases. Communities disintegrated in the worst-affected areas, and there was massive forced migration. As much as one third of the population left Afghanistan, for example, during the 1990s. There were also massive deaths from war-induced famines, notably in the Sudan. Table 1 summarises the aggregate development costs in particular economies by adding up lost production and higher infant deaths as compared with what a country would have achieved had its performance followed the average behaviour of countries in the region, excluding those countries at war. What is of interest is that while the costs were heavy in most cases, in some cases growth and infant mortality rates performed better than the regional comparator. This was the case for four countries in terms of infant mortality - showing that government policy, even during conflicts, can protect aspects of health. But for economic growth, significant above-regional growth rates were only observed in the case of Sri Lanka. This was a war confined to one part of the country and much development expenditure continued throughout the war. The same would apply to the wars in Uganda in the 1990s. But extensive recent wars, like that of the Congo, are likely to have had huge economic costs. 
Table 1: Estimates of cumulative costs of war

\begin{tabular}{|l|l|l|l|}
\hline Country & $\begin{array}{l}\text { War- } \\
\text { affected } \\
\text { period }^{\mathrm{a}}\end{array}$ & $\begin{array}{l}\text { Additional } \\
\text { cumulative } \\
\text { infant deaths } \\
\text { as share of the } \\
1995 \text { pop. }(\%)^{\mathrm{b}}\end{array}$ & $\begin{array}{l}\text { Number of additional } \\
\text { infant deaths over } \\
\text { war } \\
\text { years }\end{array}$ \\
\hline Angola & $1974-95$ & 0.73 & 80,300 \\
\hline Burundi & $1987-95$ & 0.13 & slight plus \\
\hline Ethiopia & $1973-95$ & 1.57 & 7,800 \\
\hline Liberia & $1984-95$ & 1.76 & 879,200 \\
\hline Mozambique & $1980-95$ & slight improvement & not applic. \\
\hline Sierra Leone & $1990-95$ & 0.57 & 22,800 \\
\hline Somalia & $1987-95$ & 0.31 & 29,760 \\
\hline Sudan & $1983-95$ & 0.22 & 59,400 \\
\hline Uganda & $1970-90$ & 2.03 & 385,700 \\
\hline El Salvador & $1978-95$ & improvement & not applic. \\
\hline Guatemala & $1965-95$ & improvement & not applic. \\
\hline Nicaragua & $1977-93$ & 0.53 & 21,200 \\
\hline Iran & $1977-93$ & 0.37 & 236,800 \\
\hline Iraq & $1979-91$ & 1.5 & 300,000 \\
\hline Cambodia & $1970-1994$ & 3.18 & 318,000 \\
\hline Vietnam & $1970-82$ & improvement & not applic. \\
\hline
\end{tabular}

a. The war-affected period is defined as the year preceding the outbreak of conflict and the five years following the estimated end of the war.

${ }^{b}$ Estimated as the difference in actual infant deaths over the war years from those that would have occurred if the country had improved its IMR at the same rate as the average for non-war countries in the region.

${ }^{c}$ Estimated as the difference in actual per capita incomes over the war years from those that would have occurred if the country had grown at the same rate as the average for non-war countries in the region.

Source: Stewart, Fitzgerald and associates, 2003, vol 1, Table 4.17

The generally negative impact on economic growth, capital assets, and social services and outcomes supports the view that serious conflict has a negative impact on development. But the variation in performance of both economic and social indicators suggests that such negative impacts may be potentially avoidable. Policies adopted during conflict can reduce the ongoing human and development costs. This is rarely recognized by the development community which tends to confine its efforts to humanitarian relief during conflict.

\section{How Development Affects Security}

A popular explanation of violence points to cultural or ethnic differences as being fundamentally responsible - that there is some innate propensity among peoples from different cultures to fight each other, for domination or autonomy. For example, in the former Yugoslavia, it has been argued that age-old ethnic enmities which had been suppressed under communism came to the fore again in the post-communist era; similar statements are frequently made in many other conflicts, for example, about Tutsis and Hutus in Burundi/Rwanda. Such explanations give no role to development policy in the solution of conflict. 
It is certainly true that many conflicts have a cultural dimension, i.e., the groups that fight perceive themselves as belonging to a common culture (ethnicity or religion) and are partly fighting for cultural autonomy. Moreover, ethnicity is often used during conflict to mobilize support. Yet it is evident that this is not an adequate explanation for conflict since many multicultural societies live together relatively peacefully, and others do so for decades before conflict erupts. Moreover, given that cultural differences are not innate but are developed and accentuated by social and political events, by leaders and the media, a cultural explanation is clearly insufficient because one needs to explain why particular cultural differences have developed and become salient. ${ }^{7}$ Many tribal distinctions in Africa, for example, were created by the colonial powers: 'Almost all recent studies of nineteenth century pre-colonial Africa have emphasised that far from there being a single 'tribal' identity, most Africans moved in and out of multiple identities, defining themselves at one moment as subject to this chief, at another moment as a member of that cult, at another moment as part of this clan, and at yet another moment as an initiate in that professional guild' (Ranger 1983, p. 248).

Consequently, cultural explanations alone are insufficient to explain why cultural differences become salient at some times, so much so that they appear as the prime cause of bitter conflicts, and seem relatively insignificant at other times. We need, therefore, to go beyond cultural explanations of conflict to economic and, perhaps, political explanations.

A variety of economic explanations have been suggested to explain the incidence of conflict - these relate both to the level of development (as measured e.g., by per capita incomes and poverty levels), and to its nature. Such explanations then tie the cause of conflict to the nature of development.

\section{Economic explanations}

I shall differentiate three economic hypotheses explaining contemporary intra-state wars: group motivation associated with group inequalities; private motivation and incentives; and a failure of the social contract, stemming from economic failure and poor government services. It is common today to pose economic motives as being represented by 'greed' or 'grievance', following the work of Collier and the World Bank, while later versions of Collier and Hoeffler's analysis have added 'opportunity' (see Collier and Hoeffler 2000). I find this dichotomy oversimplifies and neglects important economic, social and political sources of conflict. The discussion below will show how greed, grievance and opportunity fit into the three-fold classification.

(i) Group motivation and horizontal inequalities. Most internal conflicts consist in fighting between groups - some who wish to gain independence or takeover the state and some who resist this, wishing to preserve their control, and/or the integrity of the nation (Gurr 1993; Horowitz 1985). These groups are united in a common purpose. While individual motivation can be important, as noted below, in almost all cases of political struggle as against criminality, group motivation is essential.

\footnotetext{
${ }^{7} \mathrm{~A}$ few anthropologists seem to support the primordial view, arguing that 'ethnicity is a cultural given, a quasi-natural state of being determined by one's descent and with, in the extreme view, socio-biological determinants' (Douglas 1988, p. 192). This view has also been associated with Smith - e.g., Smith (1986); and also with Soviet ethnobiologists - e.g., Bromley (1974). But the majority of anthropologists argue that that ethnicity is 'constructed' often for instrumental reasons. See e.g., Cohen (1969), Glazer and Moynihan (1975), Turton (1997).
} 
In many cases, the groups who fight share cultural identity - arising, for example, from tribal affiliation, 'race', or religion. When such groups are also differentiated by geographic location, the conflicts tend to become separatist. When cultural differences coincide with economic and political differences between groups, this can cause deep resentments which may lead to violent struggles. As Cohen (1974) stated, 'Men may and do certainly joke about or ridicule the strange and bizarre customs of men from other ethnic groups, because these customs are different from their own. But they do not fight over such differences alone. When men do, on the other hand, fight across ethnic lines it is nearly always the case that they fight over some fundamental issues concerning the distribution and exercise of power, whether economic, political, or both' (p 94).

Where some groups suffer economically, socially or politically compared with other groups in society, leaders can use the resentments caused by the deprivations experienced by many of the members of the group to mobilise support. Where political redress is not possible, they may resort to war. Group differences, termed horizontal inequalities, may thus form a fundamental cause of war. Such horizontal inequalities have many dimensions - economic, political and social (see Table 2 for country-specific examples). Not only the deprived, but also relatively privileged groups may sometimes be motivated to fight in order to protect their share of resources from being encroached on by those who are relatively deprived. Geographic inequalities, especially when they coincide with some cultural differences, often lead to demands for autonomy or independence, as in parts of Indonesia. 
Table 2: Some examples of horizontal inequality in conflict situations

\begin{tabular}{|c|c|c|c|c|}
\hline \multirow{2}{*}{$\begin{array}{l}\text { Categories of } \\
\text { differentiation }\end{array}$} & \multirow{2}{*}{$\begin{array}{l}\text { Political } \\
\text { participation }\end{array}$} & \multicolumn{2}{|l|}{ Economic } & \multirow{2}{*}{$\begin{array}{l}\text { Social access } \\
\text { and situation }\end{array}$} \\
\hline & & Assets & $\begin{array}{l}\text { Employment } \\
\text { and incomes }\end{array}$ & \\
\hline \multirow[t]{5}{*}{$\begin{array}{l}\text { Selected } \\
\text { elements }\end{array}$} & \multirow[t]{3}{*}{$\begin{array}{l}\text { Participation } \\
\text { in } \\
\text { government } \\
\text { Fiji, Burundi, } \\
\text { Bosnia and } \\
\text { Herzogovinia, } \\
\text { Uganda, } \\
\text { Sri Lanka }\end{array}$} & $\begin{array}{l}\text { Land } \\
\text { Fiji, } \\
\text { Cambodia } \\
\text { El } \\
\text { Salvador, } \\
\text { Haiti }\end{array}$ & $\begin{array}{l}\text { Incomes } \\
\text { Malaysia, S. } \\
\text { Africa, Fiji, } \\
\text { Chiapas }\end{array}$ & $\begin{array}{l}\text { Education } \\
\text { Rwanda, } \\
\text { Burundi, } \\
\text { Haiti, S. } \\
\text { Africa, } \\
\text { N. Uganda, } \\
\text { Kosovo }\end{array}$ \\
\hline & & $\begin{array}{l}\text { Privately } \\
\text { owned } \\
\text { capital } \\
\text { Malaysia, } \\
\text { S. Africa, } \\
\text { Burundi }\end{array}$ & $\begin{array}{l}\text { Government } \\
\text { employment } \\
\text { Sri Lanka, Fiji }\end{array}$ & $\begin{array}{l}\text { Health } \\
\text { services } \\
\text { Burundi, } \\
\text { N. Uganda, } \\
\text { Chiapas }\end{array}$ \\
\hline & & $\begin{array}{l}\text { Governme } \\
\text { nt } \\
\text { infrastruct } \\
\text { ure } \\
\text { Chiapas, } \\
\text { Mexico, } \\
\text { Burundi }\end{array}$ & $\begin{array}{l}\text { Private } \\
\text { employment } \\
\text { Fiji, Uganda, } \\
\text { Malaysia }\end{array}$ & $\begin{array}{l}\text { Safe water } \\
\text { N. Uganda, } \\
\text { Chiapas }\end{array}$ \\
\hline & \multirow[t]{2}{*}{$\begin{array}{l}\text { Army/police } \\
\text { Fiji } \\
\text { N. Ireland } \\
\text { Burundi, } \\
\text { Kosova }\end{array}$} & $\begin{array}{l}\text { Aid } \\
\text { Afghanista } \\
\text { n, Sudan, } \\
\text { Rwanda }\end{array}$ & $\begin{array}{l}\text { 'Elite' } \\
\text { employment } \\
\text { S. Africa, Fiji, } \\
\text { N. Ireland }\end{array}$ & $\begin{array}{l}\text { Housing } \\
\text { N. Ireland }\end{array}$ \\
\hline & & $\begin{array}{l}\text { Natural } \\
\text { resources } \\
\text { Liberia, } \\
\text { Sierra } \\
\text { Leone, } \\
\text { Indonesia }\end{array}$ & $\begin{array}{l}\text { Unemployment } \\
\text { S. Africa, } \\
\text { N. Ireland }\end{array}$ & $\begin{array}{l}\text { Poverty } \\
\text { Chiapas, } \\
\text { Uganda, } \\
\text { S. Africa }\end{array}$ \\
\hline
\end{tabular}

(ii) Private motivation. War confers benefits on individuals, as well as costs. The analysis of some political sociologists, such as Keen and Duffield, and economists, such as Collier and Hoeffler, and the World Bank, has emphasised private or individual motivation as the fundamental cause of conflict. The 'private motivation' hypothesis argues that the net economic advantages of war to some individuals motivates them to fight (see Keen, 1994; 1998; Collier and Hoeffler 2000). Keen (1998) lists many ways in which war confers individual 
benefit on particular categories of people. For example, it permits people, especially uneducated young men, to gain employment as soldiers; it offers opportunities to loot; to profiteer from shortages and from aid; to trade arms, and to carry out illicit production and trade in drugs, diamonds, timber and other commodities. Where alternative opportunities are few, because of low incomes and poor employment, and possibilities of enrichment by war considerable (for example, where there are valuable resources such as diamonds which can readily be mined, or stolen and traded), the incidence and duration of wars are then likely to be greater - this is the 'greed' hypothesis of Collier and Hoeffler which has its basis in rational choice economics. It has been argued that conflicts often persist because some powerful actors benefit through the manipulation of scarcity, smuggling, etc., and have no interest in resolving the conflict.

However, purely individualistic explanations of conflict are inadequate as the main or full explanation of many violent struggles because most wars are between groups, and the groups fight according to a common agenda. Nonetheless, it is clear that individual motivation - making gains or avoiding costs - does play a part in motivation, especially once conflicts are underway, helping to prolong them. In some cases, conflicts seem to transmute from being primarily ideological group conflicts to being primarily venal, mainly concerned with individual gain. According to Keen (1998), 'increasingly civil wars that appear to have begun with political aims have mutated into conflicts in which short-term benefits are paramount' (p. 12). Colombia, perhaps, is an example. ${ }^{8}$

(iii) Failure of the social contract. This explanation refers to the failure of the state to play its part in the social contract - in delivering economic benefits or social services. ${ }^{9}$ It derives from the view that social stability is implicitly premised on a social contract between the people and the government: according to this (hypothetical) contract, people accept state authority so long as the state delivers services and provides reasonable economic conditions (employment and incomes). With economic stagnation or decline, and worsening state services, the social contract breaks down, and violence results. Hence high (and rising) levels of poverty and a decline in state services would be expected to cause conflict (Nafziger and Auvinen 2002 ). High (vertical) inequality might be associated with such a failure, unless accompanied by populist measures to compensate the deprived. The concept of 'grievance' broadly refers to the same set of causes as those classified here as constituting a breakdown of the social contract.

\section{Political explanations}

There are also political factors which may contribute to the outbreak of violence, generally in combination with economic and cultural factors. One element is the strength of the state: a highly repressive state can suppress potential conflict (e.g., in Indonesia under Soharto; or ethnic conflicts which were suppressed under strong communist regimes). At the other end of the spectrum, democratic institutions can allow change to be achieved peacefully. But this will not always occur. A particular problem arises where there is majoritarian democracy and one ethnic group is in a majority - as for example, in Sri Lanka or Northern Ireland. As noted in the discussion of group motivation,

\footnotetext{
${ }^{8}$ Guaqueta (2003), however, argues that ideological and class motives persist.

${ }^{9}$ Addison and Murshed (2001) have used the idea of a breakdown of the social contract to refer more generally to institutional weakness.
} 
horizontal inequalities in political participation may be an important cause of violence.

A political explanation often advanced (e.g. Väyrynen 2000) is the existence of a failed state, which is unable to keep law and order or provide essential services. ${ }^{10}$ Such states are associated with and partly responsible for some of the factors above, notably economic stagnation and reduced social services. A more general indicator of a failed state is a low level of revenue. For example, Uganda's revenue declined to 5 per cent of GDP during the Amin years - but clearly, as with many other variables associated with state failure, this is as much a result as a cause of violence.

\section{Empirical evidence on the causes of conflict}

A review of evidence from both case studies and statistical analyses suggests that each economic explanation has something to contribute to explaining serious conflict.

- $\quad$ Group inequality. Abundant case study evidence shows sharp horizontal inequalities between groups in conflict (Nafziger, Stewart and Värynen 2000, Stewart 2001). Group inequalities in political access are invariably observed hence the resort to violence rather than seeking to resolve differences through political negotiation. Group inequalities in economic dimensions are frequent; for example, in the state of Chiapas in Mexico; between Catholics and Protestants in Northern Ireland; between Moslems and Hindus in India; between ethnicities and classes in Nepal; and groups of different ethnicity in Kosovo, Rwanda and Burundi. In some cases, conflict may be precipitated by the relatively richer areas (e.g., Biafra, the Basque country in Spain and richer regions in Indonesia). According to the case study evidence, horizontal inequalities appear to be most likely to lead to conflict where they are significant, consistent across dimensions, and widening over time.

Systematic cross-country evidence on this issue is rare because of lack of comprehensive data on incomes, assets or other relevant elements by cultural group. However, Gurr 1993 has classified 233 politicised communal groups in 93 countries according to political, economic and ecological differences, and found that most groups suffering horizontal inequalities had taken some action to assert group interests - ranging from non-violent protest to rebellion.

- $\quad$ Private motivation. A number of case studies support the view that private motivation plays an important role in prolonging, if not causing, conflict in some countries. Keen and Reno's work on the Sudan, Sierra Leone and Liberia are powerful examples. (Keen 1994, 2001). However, other elements causing conflict have also been generally present. For example in Sierra Leone, there are elements of class conflict as well as short-term benefit maximisation, while in Liberia, ethnic inequalities combine with profit maximising. Collier and Hoeffler test the 'greed' hypothesis with a rather crude measure of resource riches; ${ }^{11}$ they find a significant association with conflict, which peaks at an intermediate level. ${ }^{12}$ However, de Soysa (2000) finds that the overall per capita availability of natural resources is unrelated to civil war, but there is a highly

\footnotetext{
10 'Humanitarian crises are more likely to occur where the state is weak and venal' (Nafziger and Auvinen, 2002, p. 154).

${ }_{11}$ The measure adopted is natural resource production as a share of GDP.

${ }^{12}$ Rather complex and unconvincing reasons have been advanced for this peak. Cramer (2002) has criticised the assumptions underlying the Collier and Hoeffler methodology, while Humphreys (2002) has put forward eight alternative explanations for the econometric findings.
} 
significant association when only mineral resources are included. According to Collier and Hoeffler, statistical evidence suggests higher per capita income and greater secondary male education reduce the risk of war, arguing that this is because they increase the opportunity costs of fighting. They argue that 'greed' outperforms 'grievance' in explaining conflict.

Nonetheless, a recent collection of case studies from all over the world, concludes that

'very few contemporary conflicts can be adequately captured as pure instances of "resource wars" or conflicts caused by "loot seeking" on the part of either insurgents or state actors. Economic incentives have not been the only or even the primary causes of these conflicts' (Ballentine and Sherman 2003, p. 259-260).

- $\quad$ Failure of the social contract. Considerable evidence from econometric studies shows that conflict incidence is higher among countries with lower per capita incomes, life expectancy and economic growth (Nafziger and Auvinen 2000, Elbadawi 2001, Collier and Hoeffler 2000). Of course, there is a problem about the direction of causality since the conflicts themselves affect people's incomes and health negatively, but tests for the direction of causality suggest the negative relationship from poverty etc. to conflict is stronger than the reverse relationship (Nafziger and Auvinen 2002). The numerous statistical investigations of the association between vertical income distribution and conflict produce inconsistent results (Nafziger and Auvinen 2000, Collier 1999).

While each of the explanations thus finds some support, none accounts for all of the variance. What each hypothesis identifies is factors likely to predispose to conflict, rather than simple cause and effect. It should be emphasised that the economic explanations are not necessarily alternatives. Each may apply in some conflicts, and more than one hypothesis might hold true for some. For example, the conflict in the Sudan is both an example of horizontal inequality (with the South being heavily deprived), and one of powerful private gains which perpetuate the struggle. Economic stagnation and decline may be a feature (and also a consequence) of the wars in Sierra Leone and Somalia, but they are not a factor in Sri Lanka. While environmental poverty has plausibly been argued to be a significant element in the conflict in Rwanda, horizontal inequalities were evidently also important. Yet in other cases, environmental pressure does not seem to have been important - for example, in the former Yugoslavia. One factor that all investigations find important is a history of conflict in the country. This is partly because the same structural factors that predisposed to war initially often continue, and partly because the possibilities of mobilising people on group lines by calling on historical memories are stronger when there is a history of conflict.

\section{Evidence on political hypotheses}

As noted already, there is strong case study evidence supporting the view that horizontal inequalities in political control are a very common element in many conflicts, hence the frequent separatist demands. Statistical investigations of the type of political regime most liable to violence suggest that 'intermediate' regimes, i.e., those between authoritarian regimes and established democracies are most conflict-prone (Reynal-Querol 2001). The 'failed state' hypothesis gets strong support from case studies, but again there is an issue of cause and effect. The strongest correlation, statistically, is found between previous history of conflict and a new outbreak (e.g., Nafziger and Auvinen, 
2000). This could be due to the importance of past conflict in enforcing cultural identity; or because the reasons for conflict initially (such as group inequalities, weak states, poor social services, etc.) persist. One statistical investigation gave support to the latter explanation (Walter 2001).

\section{Development policies}

While I have differentiated three distinct hypotheses concerning the economic and political causes of war, there are some major overlaps in the variables they point to as being significant contributory factors in causing conflict. Table 3 provides a summary of these variables, which need to be targeted in development policies aimed at preventing conflict. Variables 1-6 are economic variables which can be affected by development policies. They suggest the need for a range of development policies if the likelihood of conflict is to be reduced. It is clear that what matters is not just the level of development, as measured by per capita incomes. Levels of poverty, horizontal inequalities and public expenditure on social services are all relevant variables, though further research is needed to assess how important each one is, and this is likely to vary across societies. Variable six, high levels of natural resources, is difficult to tackle since these either exist or they do not, but the possibility of developing national and international policies which control the individual rents that can be made from natural resources could be explored.

The political variables are also important. The automatic advocacy of democracy needs to be reconsidered, and a concept of structured democracy explored, which would limit the possibility of domination of the system by one or a few groups. Rapid transitions from autocracy to multiparty democracy should also be avoided. 
Table 3: Variables associated with violent conflict

\begin{tabular}{|c|c|c|}
\hline $\begin{array}{l}\text { Economic variables } \\
\text { associated with } \\
\text { conflict }\end{array}$ & $\begin{array}{l}\text { Evidence of } \\
\text { association with } \\
\text { conflict }\end{array}$ & Hypotheses \\
\hline $\begin{array}{l}1 . \\
\text { Decline/stagnation in } \\
\text { per capita incomes }\end{array}$ & $\begin{array}{l}\text { Cross-country and } \\
\text { case study support. }\end{array}$ & $\begin{array}{l}\text { Failure of social } \\
\text { contract; environmental } \\
\text { degradation; low } \\
\text { opportunity costs of } \\
\text { war - private motive. }\end{array}$ \\
\hline $\begin{array}{l}\text { 2. Horizontal } \\
\text { inequality }\end{array}$ & $\begin{array}{l}\text { Cross-country and } \\
\text { case study support. }\end{array}$ & $\begin{array}{l}\text { Group motives for } \\
\text { conflict (horizontal } \\
\text { inequalities). }\end{array}$ \\
\hline 3. Vertical inequality & $\begin{array}{l}\text { Conflicting } \\
\text { evidence. }\end{array}$ & $\begin{array}{l}\text { Failure of social } \\
\text { contract. }\end{array}$ \\
\hline 4. High poverty & $\begin{array}{l}\text { Same evidence as } \\
\text { for per capita } \\
\text { incomes. }\end{array}$ & $\begin{array}{l}\text { Failure of social } \\
\text { contract; private } \\
\text { motives. }\end{array}$ \\
\hline $\begin{array}{l}\text { 5. Reduced } \\
\text { government revenue } \\
\text { and social } \\
\text { expenditure }\end{array}$ & $\begin{array}{l}\text { Case study } \\
\text { evidence. Limited } \\
\text { statistical } \\
\text { investigation. No } \\
\text { evidence for } \\
\text { association with } \\
\text { IMF programmes. }\end{array}$ & $\begin{array}{l}\text { Failure of social } \\
\text { contract; weak } \\
\text { government ability to } \\
\text { suppress conflict - } \\
\text { failed state. }\end{array}$ \\
\hline $\begin{array}{l}\text { 6. High levels of } \\
\text { natural resources }\end{array}$ & $\begin{array}{l}\text { Support for mineral } \\
\text { resources only. }\end{array}$ & $\begin{array}{l}\text { Private motives (and } \\
\text { financing). }\end{array}$ \\
\hline \multicolumn{3}{|l|}{$\begin{array}{l}\text { Political factors } \\
\text { associated with } \\
\text { conflict }\end{array}$} \\
\hline 7. History of conflict & $\begin{array}{l}\text { Strong statistical } \\
\text { and case study } \\
\text { evidence. }\end{array}$ & $\begin{array}{l}\text { Persistence of } \\
\text { economic conditions } \\
\text { giving rise to conflict; } \\
\text { memory of conflict } \\
\text { acting as mobilising } \\
\text { agent. }\end{array}$ \\
\hline $\begin{array}{l}\text { 8. State expenditure } \\
\text { low proportion of } \\
\text { national income }\end{array}$ & Casual evidence. & Weak states. \\
\hline $\begin{array}{l}\text { 9. Unequal access } \\
\text { to political power } \\
\text { among groups }\end{array}$ & $\begin{array}{l}\text { Case study and } \\
\text { statistical evidence. }\end{array}$ & Horizontal inequalities. \\
\hline $\begin{array}{l}\text { 10. Intermediate } \\
\text { political regime }\end{array}$ & $\begin{array}{l}\text { Statistical and case } \\
\text { study evidence. }\end{array}$ & $\begin{array}{l}\text { Inability to negotiate } \\
\text { change or suppress } \\
\text { violence. }\end{array}$ \\
\hline
\end{tabular}

\section{The security/development/security nexus}

In the context of internal wars in developing countries, the previous sections of this paper have argued that promoting security is a substantial part of what we mean by societal progress; that conflict has heavy development costs so that 
promoting security is instrumental to it; and that inclusive patterns of development are an important element in avoiding conflict, so development is instrumental for the achievement of security. This combination of arguments means that vicious cycles of lack of development leading to conflict leading to lack of development can readily emerge. We can observe this situation in many countries in Africa. Conversely, virtuous cycles should also be possible, with high levels of security leading to development and development further promoting security. But unfortunately the virtuous cycle can more readily be broken because it is easy to have relatively high levels of security without necessarily experiencing economic growth, or to have high levels of security and economic growth, but not inclusive growth so the potential for conflict remains. The first, security-cum-stagnation can be observed in a number of Latin American countries; while the second, non-inclusive growth, seems to be occurring in some Asian countries, like India and China. Both situations pose potential threats to security.

\section{Global Aspects of the Security/Development Connections}

The previous sections have argued that there is a close three-way connection between security and development within developing countries. Is this also true of global security? And if so what are the implications? This section will consider each of the connections discussed at a global level.

\section{Security and welfare}

It seems plausible to argue that for everyone, rich or poor, located in developing or developed countries, security is an important constituent of well-being. Unfortunately, most of the investigations into the determinants of individual wellbeing do not enter this as an explicit variable. However, there is strong evidence that believing others to be trustworthy is a determinant of well-being: according to Helliwell 'differences in national average trust over time and across countries have a large and significant effect on subjective well-being' (Helliwell, 2002, p 19), while he finds that a combined index of quality of governance (which includes 25 indicators of which several relate to violence and stability) also has a significant impact. Both these indicators, however, relate to national rather than international security.

Can we assume that international threats would have similar effects? This depends on how big the perceived threats are, as well as on their impact on well-being. A study of perceived risks from terrorism in Sweden, post 9/11, suggested that the fears were not very high, and diminished as time elapsed. In a July 2002 survey, the risk ratings of five terrorism-related events were less than the average rating for 46 potential hazards, although a study conducted in October 2001 had found terrorism to be perceived as the highest threat. A survey of EU countries in May 2003, however, showed that terrorism was regarded as the greatest threat, with $80 \%$ of those interviewed counting it as a fear. ${ }^{13}$ But it was not regarded as the most important problem nations faced. Unemployment was regarded as the most important problem facing nations $(41 \%)$ while terrorism was the fourth problem among EU citizens (regarded as

\footnotetext{
${ }^{13}$ Among EU candidate countries, there were very different answers, with international terrorism being the lowest of ten fears (only 16\% putting it as a fear), and conventional and nuclear war, epidemics, ethnic conflicts, nuclear accidents, weapons of mass destruction spreading and organised crime all coming higher in the list.
} 
most important by 19\%), coming after crime and the economic situation as well as unemployment. (Eurobarometer, 2003).

On the basis of this very limited review of evidence, we can conclude that current global threats to security have an adverse impact on well-being, but we would need more evidence before we can assess how important this impact is. It seems that other risks loom larger for many people.

\section{Security and economic and social development}

As argued above, civil wars in developing countries certainly almost always reduce economic growth and usually worsen social development. However, there is not an automatic translation between global threats to security and global growth. To analyse this, it is helpful to differentiate three types of insecurity: terrorist incidents; advanced country government reactions to them in the form of military action in developing countries, such as has occurred in Afghanistan and Iraq; and the finance of peace-making or keeping activities in civil wars, undertaken partly in order to reduce global insecurity. Costs include budgetary costs for prevention (on surveillance or defence expenditure); budgetary costs of military operations, peace-keeping and reconstruction; and economic costs resulting from global insecurity, such as reduced tourism, air travel, investment and other effects on the world economy (e.g., via changes in oil prices). More research is needed to identify the nature and magnitude of each of these effects.

The large rise in defence expenditure over recent years in the U.S. can be attributed to all three types of insecurity identified above. From 2001 to 2004, the increase is estimated at $\$ 90$ bn or 27 per cent of the 2001 level. USAID (grants and loans) in 2001 was $\$ 10.7$ bn, so the increase in defence expenditure is over eight times the total aid. Military operations by the U.S. alone cost around $\$ 1$ bn a month for Afghanistan and \$4.4 bn for Iraq (some of which costs are presumably included in the above defence estimates). There is uncertainty about reconstruction costs. For Iraq, estimates range from $\$ 100$ bn to $\$ 600$ bn over a decade, while for Afghanistan, estimates are much lower - of the order of $\$ 15 \mathrm{bn} .{ }^{14}$ One estimate suggests that peace-keeping operations in Somalia, Sierra Leone and Liberia have cost the international community $\$ 2.8$ bn in budgetary outlays.

These are all rough estimates, subject to correction. But they do suggest relatively heavy budgetary costs. Although large absolutely, they are not large in relation to US GDP (below 1 per cent) or to its federal budget (below 5 per cent). To date in the U.S., these additional expenditures have been partly financed through deficit financing, consequently reducing the short run diversion of resources from the social sectors. But this will not be sustainable in the longer run, and the extra military expenditures will have costs in terms of reduced government and private expenditures in other areas.

The indirect consequences for national income depend on the nature and size of the incidents. So far the consequences seem to be much greater for small economies than for the large economies of advanced nations. For example, the Kenyan economy was badly affected by actual as well as rumoured terrorism, particularly its tourist sector. In Indonesia, too, depressed tourism and international investment can be attributed to terrorist incidents. Small developed

\footnotetext{
${ }^{14}$ Sources for these data include: Brainard and O'Hanlon (2003); Ashdown (2003); Kaysen et al.(2002).
} 
countries, such as the Basque country and Northern Ireland, have also been evidently negatively affected (in these cases by home-grown terrorism), with low growth relative to non-affected neighbours. ${ }^{15}$

More systematic research is needed to identify such indirect economic effects on larger developed countries. Some negative effects are apparent, including blips in tourism in the U.K., associated with IRA bombs over the years; a major downturn in tourism and air travel following 9/11; and quite heavy reconstruction costs in the case of 9/11. Yet, governments have partially compensated their airline industry and economic recovery soon followed, helped by the massive growth in defence expenditure in the U.S., and expansion in other industries involved in surveillance and security. This tentative 'optimistic' conclusion about the cost of global insecurity is partly because the actual terrorist incidents (even 9/11) have been quite small in relation to the size of the economy. Moreover, amongst other hazards people face, most of them have been located in developing countries, and developed countries are in a position to take counter-measures which reduce the economic costs. The economic and social costs therefore have fallen to a considerable extent on the countries where terrorism or military action takes place, although reconstruction expenditures financed from abroad partially compensate.

We can conclude, rather tentatively and subject to further research, that at a global level recent security failures have had significant economic costs, but these have been proportionately less heavy for developed countries.

\section{Development and security}

Here there seem to be strong parallels with the developing country situation, with a similar set of causes of global insecurity. In particular, a combination of cultural, economic and political factors is involved.

As in civil wars in many developing countries, cultural clashes appear to play an important role at the global level. Indeed some, like Huntington, attribute conflicts to the 'clash of civilisations', the clash being between the West and Moslem societies and peoples.

In support of a cultural explanation, it is true that the global conflict is often presented in cultural terms - in the rhetoric and mobilization of both sides. For example, Bin Laden has stated that 'to kill Americans and their allies, both civil and military, is the individual duty of every Muslim who is able, until the Aqsa mosque [in Jerusalem] and the Haram mosque [in Mecca] are freed from their grip, and until their armies, shattered and broken winged, depart from all the lands of Islam' (Declaration of the World Islamic Front against the Jews and Crusades, $23^{\text {rd }}$ February 1998) From a Western perspective, a major Pentagon adviser has stated: 'Satan wants to destroy this nation, he wants to destroy us as a nation, and he wants to destroy us as a Christian army', arguing that the Moslem world hates Americans because 'we are a nation of believers' (W. Boykin, quoted in Hersch 2003). This extreme position is not widely shared, but mobilizing Western populations under the banner of Western values, including 'freedom' and 'democracy' is common, as is labelling all Moslems as being potential terrorists. The cultural element is also indicated by the fact that few

\footnotetext{
${ }^{15}$ One estimate suggests that terrorism in the Basque country accounted for a decline of 10 percentage points in GDP compared with a counterfactual (Abadie 2001).
} 
Moslems, however secular, support Western coalition activities in Iraq and elsewhere. Cultural ties that cross nations mean that an incident in one place can have repercussions elsewhere (e.g., the Israel/Palestine situation affects perceptions of Moslems the world over; and discrimination in one country e.g., the U.K. - can generate support for Moslem activities in the Middle East or Indonesia.

Yet, as in the developing country situation, cultural clashes are clearly not the whole explanation; for one thing, there have been long periods with no such clashes on any serious scale; secondly, there are many societies which are Moslem and have good relations with the West (such as Morocco or Egypt); thirdly, Moslems as a whole are by no means homogeneous, with many serious religious divisions, ${ }^{16}$ and also many that have adopted 'Western' values - we can see that clearly, for example, in Saudi Arabia, Pakistan, Algeria and Iraq. All these situations suggest that a clash of civilizations is not inevitable, and we need to seek alternative explanations.

Turning to economic factors which encourage such cultural mobilization, two of the earlier explanations seem particularly plausible - the existence of horizontal inequalities and the role of 'greed'.

We are confronted with blatant horizontal inequalities between Moslems and Westerners, as between nations and also within them. For example,

- there is evidence of widening differentials between Moslems and Westerners in the world as a whole. Between 1975 and 1999, annual growth in per capita incomes in Arab states was 0.3 per cent, while that of high-income OECD countries was 2.2 per cent. In 1999, PPP adjusted per capita incomes in the high-income OECD countries was nearly six times that of the Arab states.

- there is a widening gap in per capita incomes between Israel and Palestinians; Israeli per capita incomes have been growing at about 5 per cent p.a. (1990-1999), while the CIA estimates that GDP in Palestine has been declining at a rate of 7.5 per cent (dates not specified). Palestinian incomes per capita are roughly 8 per cent of Israeli incomes. The unemployment rate in the areas under the Palestinian Authority is 40 per cent compared with 9 per cent in Israel. There are also inequalities between Jews and Moslems within Israel - for example, the infant mortality rate among Moslems is double that among Jews.

- in Western countries, the Moslem population systematically does less well in every dimension than majority population; e.g., Germany (Turks), France (Algerians), the U.K. (Moslems from Asian subcontinent). For example, in the UK, unemployment rates among predominantly Moslem groups (people from Pakistan and Bangladesh) are higher than all other categories; nearly $60 \%$ of the Moslem group are classified as low-income, compared with $17 \%$ among whites; and completion of 5 or more GSCEs at secondary school is just over $20 \%$ among Pakistani and Bangladeshi boys compared with $45 \%$ among white boys. (Statistics from the UK Office of National Statistics, quoted in the Financial Times $3 / 4$ April, 2004.)

These large and widening horizontal inequalities (which extend to political influence as well as economic resources at a global level) are undoubtedly one factor which helps explain the current situation. More generally, high levels of poverty in much of

\footnotetext{
${ }^{16}$ A major division is between Sunnis and Shiites, but there are many others (see e.g., Ayubi 1991, Ahmed 2002, Gregorian 2003).
} 
the world, especially relative to standards elsewhere, make it easy to mobilise populations against the West. Cultural differences provide a ready unifying banner.

The second economic explanation that seems to make sense is the 'greed' hypothesis. Few would explain the global situation entirely in terms of greed - clearly this is not Bin Laden's major motivation; he would be far better off economically as a member of the wealthy family he comes from if he had never joined battle. But seeking cheap supplies of oil, profitable opportunities for oil and reconstruction companies, and an opportunity to test weapons and extend the market of the US and UK arms industry do seem to represent one plausible motive for some Western action, notably the war in Iraq. Sachs (2003), for example, has suggested that support for the Iraq war by Cheney can be explained as part of a long-term strategy to gain military domination of the Middle East in order to control its oil. The very close connections that the Bush administration and its advisers have with major industries that have gained by the war also lends support to the view that private profit maximisation may have played a role. These include Bush's own connections with the oil industry; those of Cheney with Halliburton, war-servicing and reconstruction contracts, and oil companies; and those of Rumsfeld and advisers, such as Pearle, with arms companies. ${ }^{17}$

Political factors also play a part. A common enemy helps to mobilise general political support for the President, financial support from big defence and oil companies provide major contributions to the Republican party; and the Democrats rely heavily on support from pro-Israel groups.

Hence, as in the developing country civil war case, we find that a combination of explanations seem to fit the current global conflicts. The cultural element is present as a crucial mobilising element, which becomes effective because of the presence of horizontal inequalities combined with private motivations and political objectives.

Some strong policy conclusions emerge from these economic and political explanations. First, so long as horizontal inequalities are a major element in motivating support for Al-Qaeda and similar movements, the inequalities among nations generally, and between the West and Moslem countries, as well as within Western countries between Moslems and others, need to be addressed to achieve any permanent solution to the global terror situation. Simply trying to eliminate the terrorists will not work, because so long as the inequalities persist, new leaders will be able to mobilize support.

Secondly, on the Western side especially, the greed side of the equation also needs to be tackled. This is difficult to do. In democracies, what is needed is to separate voting behaviour from private interest groups - which in principle should not be impossible since although particular groups may gain from conflict, society as a whole generally loses. ${ }^{18}$ Reform of the finance of political parties is one important mechanism for bringing about this separation, so that parties do not rely on particular interests for their finance. A second requirement is to improve the quality of information received by the voting public, so that people are presented with a more accurate balance sheet. Yet in the global context, as in particular countries, it remains easier to mobilize political support by cultural mobilization for war, than by accommodation and development aid.

\footnotetext{
${ }^{17}$ See e.g., Hartung (2003).

${ }^{18}$ However, particular countries may gain, by getting cheap access to cheap resources for example.
} 


\section{Conclusions}

Both in particular developing countries and in the world as whole, there are strong three-way connections between security and development. In both cases, societal progress requires reduced insecurity. In both cases, it seems that more inclusive and egalitarian development as between cultural groups is likely to lead to greater security. And in both cases, there are severe problems in achieving the virtuous nexus of more inclusive development, better security and more development. These problems are first, that it is easy to mobilize people politically - especially in a democracy - along cultural lines to unite against the feared 'other'; and secondly, private interests that gain from conflict can be effective in promoting or prolonging it. 
Appendix, Table 1

Twenty Five Conflicts Where More Than 2 Per Cent Of 1995 Population Died (1970-95)

\begin{tabular}{|c|c|c|c|}
\hline \multirow[t]{2}{*}{ Country } & \multirow[t]{2}{*}{ Date of war } & \multicolumn{2}{|l|}{ Deaths } \\
\hline & & '000s & $\begin{array}{l}\text { as \% of } 1995 \\
\text { population }\end{array}$ \\
\hline Cambodia & $1975-89$ & 1,221 & 12.2 \\
\hline Kuwait & $1990-91$ & 200 & 12.0 \\
\hline Rwanda & $\begin{array}{l}1992 \\
1994-5\end{array}$ & 502 & 8.4 \\
\hline $\begin{array}{l}\text { Bosnial } \\
\text { Herzogovinia }\end{array}$ & $1992-96$ & 263 & 8.0 \\
\hline Angola & 1975-95 & 750 & 7.6 \\
\hline Afghanistan & 1978-98 & 1,550 & 7.1 \\
\hline Liberia & $\begin{array}{l}1985-88 \\
1990+\end{array}$ & 155 & 6.7 \\
\hline Mozambique & $1981-90$ & 1050 & 6.2 \\
\hline Somalia & $1988+$ & 355 & 5.6 \\
\hline Burundi & $\begin{array}{l}1972 \\
1988-95\end{array}$ & 280 & 5.3 \\
\hline Lebanon & $\begin{array}{l}1975-6 \\
1982-90\end{array}$ & 163 & 4.9 \\
\hline Sudan & 1984-1995 & 1500 & 4.8 \\
\hline Uganda & \begin{tabular}{|l|}
$1971-1979$ \\
$1981-1987$ \\
\end{tabular} & 611 & 3.1 \\
\hline Nicaragua & 1978-1990 & 80 & 1.9 \\
\hline Iraq & $\begin{array}{l}1980-88 \\
1991-2\end{array}$ & $400-600$ & 3.0 \\
\hline Vietnam & $\begin{array}{l}1965-1975 ; \\
1979 ; 1987\end{array}$ & 1000 & 1.4 \\
\hline El Salvador & $1979-1991$ & 75 & 1.4 \\
\hline Guatemala & 1966-1995 & 140 & 1.3 \\
\hline Ethiopia & 1974-1992 & 614 & 1.1 \\
\hline Iran & 1978-1989 & 588 & 0.9 \\
\hline Tajikistan & $1992-95$ & 50 & 0.9 \\
\hline Bangladesh & 1971 & 1000 & 0.8 \\
\hline Cyprus & 1974 & 5 & 0.7 \\
\hline Croatia & $1991-92$ & 25 & 0.5 \\
\hline
\end{tabular}

Source: Stewart, Fitzgerald and Associates, 2001. 


\section{References}

Abadie, Alberto.and Javier Gardeazabal, 2001,"The Economic Costs of Conflict: A Case-Control Study for the Basque Country." NBER:Working Paper 8478, Cambridge, Mass.

Addison, T, and S. Mansoob Murshed. 2001. "From conflict to reconstruction: Reviving the social contract", WIDER Discussion Paper 2001/48. Helsinki: WIDER.

Ahmed, A. 1999/slam Today: A Short Introduction to the Muslim World. London: I.B. Tauris..

Ashdown, Keith. 2003."Sharing the burden: More international support needed to pay for War and post-Saddam Iraq" Taxpayers for Common Sense< March 24th.

Ayubi, N. 1991. Political Islam: Religion and Politics in the Arab World. London: Routledge.

Ballentine, Karen, and Jake Sherman. 2003. The Political Economy of Armed

Conflict. Beyond Greed and Grievance. Boulder, Colorado: Lynne Rienner.

Brainard, Lael and Michael O'Hanlon, "The heavy price of the US going it alone,"

Financial Times, 6 August 2003

Bromley, Y. 1974. "The Term 'Ethos' and Its Definition." In Soviet Ethnology and Anthropology Today, edited by Y. Bromley. The Hague: Mouton.

(CHS), 2003. Commission on Human Security. New York: Communications Development.

Cohen, Abner. 1969. Custom and Politics in Urban Africa. Berkeley: University of California Press.

- 1974. Two-Dimensional Man: An Essay on the Anthropology of Power and Symbolism in Complex Society. Berkeley: University of California Press.

Collier, Paul. 1999. "On the Economic Consequences of Civil War." Oxford Economic Papers 51, no. 1: 168-83.

Collier, Paul and Anke Hoeffler. 2000."Greed and Grievance in Civil War." 42. Washington, D.C.: World Bank, 30, 11, 1845-64. .

de Soysa, J. 2000."The Resource Curse: Are Civil Wars Driven by Rapacity or Paucity?" In Greed and Grievance: Economic Agendas in Civil Wars, edited by Mats Berdal and David Malone, 113-35. Boulder, Colorado: Lynne

Douglas, W.A. 1988. "A Critique of Recent Trends in the Analysis of Ethnonationalism." Ethnic and Racial Studies 11, no. 2: 192-206.

Elbadawi, Ibrahim, and Nicholas Sambanis. 2001."How Much War Will We See? Estimating Incidence of Civil War in 161 Countries." Policy Research Working Paper, Development Research Group, 2533, Washington, D.C.: World Bank.

Eurobarometer, 2003. 'Public Opinion in the Candidate Countries' http://europa.eu.int/comm/public_opinion/archives/cceb/2003/CCEB2003.2_Full_Re port_Final.pdf

Glazer, $\bar{N}$., and D. Moynihan. 1975. Ethnicity, Theory and Experience. Cambridge, Mass.: Harvard University Press.

Gregorian, V., 2003. Islam. A Mosaic not a Monolith. Washington, D.C.: Brookings.

Guaqueta, Alexandra. 2003."The Colombian Conflict: Political and Economic Dimensions." In The Political Economy of Armed Conflict, edited by K. Ballentine and J. Sherman, p. 73-106. Boulder: Lynne Rienner.

Gurr, T. R. 1993. Minorities at Risk: A Global View of Ethnopolitical Conflicts. Washington, D.C.: Institute of Peace Press.

Hartung, William D. 2003. How Much Are You Making on the War, Daddy? New York: Nation Books.

Hersch, Seymour (2003), "Moving targets", New Yorker, December 15.

Helliwell, John F. 2002."How's Life? Combining Individual and National Variables to Explain Subjective Well-Being." NBER Working Paper 9065 NBER: Cambridge, Mass.

Horowitz, Donald. 1985. Ethnic Groups in Conflict. Berkeley: University of California Press.

Humphreys, Macartan. 2003. "Economics and Violent Conflict." Cambridge, Mass.: Harvard University www.preventconflict.org/portal/economics/Essay.pdf

Imai, Kosuke, and Jeremy Weinstein. 2000."Measuring the Impact of Civil War." Center 
for International Development at Harvard University Working Paper 27. Cambridge, Mass: Harvard University.

Kaysen, C., S. Miller, M. Malin, W. Nordhaus, J. Steinbruner, 'War with Iraq: costs, consequences and alternatives' American Academy of Arts and Sciences, Boston, Mass.

Keen, David. 1994. The Benefits of Famine: A Political Economy of Famine Relief in Southwestern Sudan 1883-1989. Princeton: Princeton University Press. 1998. The Economic Functions of Violence in Civil Wars. Oxford: Oxford University Press for the International Institute for Strategic Studies. 2001 "Sierra Leone: War and Its Functions." In War and Underderdevelopment, edited by Frances Stewart and Valpy Fitzgerald. Oxford: Oxford University Press.

Nafziger, E. Wayne, and Juha Auvinen. 2002. "Economic Development, Inequality, War and State Violence." World Development 30, no. 2: 163-63.

Nafziger, E.Wayne, and Juha Auvinen., 2000. "The Economic Causes of Humanitarian Emergencies." In War, Hunger and Displacement: The Origin of Humanitarian Emergencies, edited by E. Wayne Nafziger, Stewart Frances and Raimo Vayrynen. Oxford: Oxford University Press.

Nafziger, E.Wayne, Frances Stewart, and Raimo Vayrynen. 2000. War, Hunger and Displacement: The Origin of Humanitarian Emergencies. Two vols. Vol. One. Oxford: Oxford University Press.

Narayan-Parker, Deepa, and Raj Patel. 2000. Voices of the Poor: Can Anyone Hear Us? Oxford: Oxford University Press for the World Bank.

Ranger, Terence. 1983."The Invention of Tradition in Colonial Africa." In The Invention of Tradition, edited by Eric Hobsbawm and Terence Ranger, p. 211-62. Cambridge: Canto.

Reynal-Querol, Marta. 2001. "Ethnicity, Political Systems and Civil War." what is this? Institut d'Analisis Economic, Campus de la UAB, Bellatera-Barcelona .

Seers, Dudley. 1971. discussion in Prospects for Employment in the Nineteen Seventies, edited by R. Robinson and O. Johnston. London: HMSO.

Sen, Amartya K. 1999. Development as Freedom. Oxford: Oxford University Press.

Smith, Antony. 1986. The Ethnic Origin of Nations. Oxford: Blackwell.

Stewart, Frances. 2001. "Horizontal Inequalities as a Source of Conflict." In From Reaction to Prevention, edited by Fen Hampson and David Malone. London: Lynne Rienner .

Stewart, Frances, Valpy Fitzgerald et al. 2001. War and Underdevelopment:The Economic and Social Consequences of Conflict. Two vols. Vol. 1. Oxford: Oxford University Press.

Turton, David. 1997. "War and Ethnicity: Global Connections and Local Violence in North East Africa and Former Yugoslavia." Oxford Development Studies 25: 77-94.

Väyrynen, Raimo. 2000. "Weak States and Humanitarian Emergencies." In War, Hunger and Displacement: The Origin of Humanitarian Emergencies, edited by E. Wayne Nafziger, Frances Stewart and Raimo Vayrynen, p. 437-79. Oxford: Oxford University Press.

Walter, Barbara. 2001. "Explaining the Recurrence of Civil War." Paper presented at the World Bank Workshop on Civil Wars and Post-Conflict Transitions, May 1820th, School of Social Sciences, UC, Irvine. 